\title{
Novel compounds for the treatment of Duchenne muscular dystrophy: emerging therapeutic agents
}

\author{
This article was published in the following Dove Press journal: \\ The Application of Clinical Genetics \\ 9 March 201I \\ Number of times this article has been viewed
}

\section{Steve D Wilton \\ Sue Fletcher}

Centre for Neuromuscular and Neurological Disorders, University of Western Australia, Crawley, Perth, WA, Australia
Correspondence: Steve D Wilton Centre for Neuromuscular and Neurological Disorders, University of Western Australia, M518, Crawley, Perth, WA 6009, Australia

Tel +6I 893463967

Fax +6I 893463487

Email swilton@meddent.uwa.edu.au
Abstract: The identification of dystrophin and the causative role of mutations in this gene in Duchenne and Becker muscular dystrophies (D/BMD) was expected to lead to timely development of effective therapies. Despite over 20 years of research, corticosteroids remain the only available pharmacological treatment for DMD, although significant benefits and extended life have resulted from advances in the clinical care and management of DMD individuals. Effective treatment of DMD will require dystrophin restitution in skeletal, cardiac, and smooth muscles and nonmuscle tissues; however, modulation of muscle loss and regeneration has the potential to play an important role in altering the natural history of DMD, particularly in combination with other treatments. Emerging biological, molecular, and small molecule therapeutics are showing promise in ameliorating this devastating disease, and it is anticipated that regulatory environments will need to display some flexibility in order to accommodate the new treatment paradigms.

Keywords: Duchenne muscular dystrophy, molecular therapeutics, small molecules

\section{Background}

Duchenne muscular dystrophy (DMD), an X-linked recessive condition caused by mutations in the huge dystrophin gene, is the most common and serious form of childhood muscle wasting, with an incidence of 1 in 3500 live male births (for review see Emery ${ }^{1}$ ). Under tissue-specific control of at least seven promoters, the full-length $427 \mathrm{kDa}$ dystrophin isoforms, encoded by 79 exons spanning $2.4 \mathrm{Mbp}$, are expressed primarily in skeletal, cardiac, and smooth muscles and brain (for review see Love et $\mathrm{al}^{2}$ ). The prevalence of DMD may be attributed to the high frequency of de novo mutations, which in turn is influenced by the size, nature, and organization of the dystrophin gene. Many dystrophin introns are fivefold to eightfold larger than the average human gene of $30 \mathrm{~kb}$ pairs. One in three cases of DMD present with no prior family history, ${ }^{3}$ and this fact, coupled with the size and complexity of the gene pose great challenges to prevention and genetic counseling programs.

In 1986/1987, mutations in the dystrophin gene were identified as causing DMD, and it became apparent that protein-truncating defects led to the severe form of muscle wasting, while in-frame deletions were often associated with a milder, less progressive form of muscle wasting, Becker muscular dystrophy (BMD). ${ }^{4-6}$ Dystrophin gene replacement therapy became a possibility, but the size, nature, and widespread expression in skeletal muscle were soon recognized as major challenges. The reading frame hypothesis proposed by Monaco et $\mathrm{al}^{6}$ holds true in the majority of cases, 
although there are some exceptions, now explained by altered gene transcript processing. ${ }^{7,8}$ More importantly, the reading frame rule offered two potential avenues for therapy: 1) Insert the dystrophin-coding sequence from mildly affected/asymptomatic BMD patients into viral vectors and exploit these smaller payloads. ${ }^{9}$ 2) Modify expression of the dystrophin gene to remove or bypass DMD-causing mutations so that a functional BMD-like dystrophin isoform is produced.

This review will focus on novel therapeutic compounds invoking avenues of intervention to either restore or supplement dystrophin and some of the potential treatments designed to modulate muscle pathology in DMD (Table 1). Each strategy offers different targets for intervention and some may be complementary, thereby providing additional possibilities for therapeutic benefit. The greatest benefit to patients is likely to be derived from dystrophin restitution; however, not all DMD mutations will be amenable to molecular interventions, and for some individuals, therapies that reduce muscle pathology may provide at least interim benefits. We will first consider potential treatments designed to modulate pathogenic processes arising from the loss of the functional $427-\mathrm{kDa}$ dystrophin isoform and then discuss nonviral approaches

Table I Ready-to-use, indirect, and dystrophin-restitution 'molecular' therapy clinical trials for DMD listed at http://clinicaltrials.gov

\begin{tabular}{|c|c|c|c|c|}
\hline Therapy & Completion & Phase & Status & $\begin{array}{l}\text { ClinicalTrials.gov identifier } \\
\text { and supporting references }\end{array}$ \\
\hline \multicolumn{5}{|l|}{ Ready-to-use/indirect therapies } \\
\hline $\begin{array}{l}\text { Randomized study of daily vs high-dose weekly } \\
\text { prednisone therapy in DMD }\end{array}$ & December 2007 & $2 / 3$ & Completed & NCT00II0669 \\
\hline $\begin{array}{l}\text { Clinical trial of coenzyme Q10 and lisinopril in } \\
\text { muscular dystrophies }\end{array}$ & December 2013 & $2 / 3$ & Recruiting & NCTOII $26697^{10,11}$ \\
\hline Tadalafil in BMD & December 2012 & 4 & Recruiting & NCTOI0705III2 \\
\hline IGF-I therapy and muscle function in DMD & November 2011 & $1 / 2$ & Recruiting & NCT0I 207908 \\
\hline Sunphenon epigallocatechin-gallate in DMD & September 2012 & $2 / 3$ & Recruiting & NCTOII 83767 \\
\hline $\begin{array}{l}\text { Long-term safety, tolerability, and efficacy of idebenone } \\
\text { in DMD (DELPHI extension) }\end{array}$ & February 201I & 2 & $\begin{array}{l}\text { Active, not yet } \\
\text { recruiting }\end{array}$ & NCT00758225 \\
\hline Extension study of ACE-03I in subjects with DMD & December 2012 & 2 & Recruiting by invitation & NCTOI $239758^{13}$ \\
\hline Study of ACE-03I in subjects with DMD & February 2012 & 2 & Recruiting & NCTOI09976/ ${ }^{13}$ \\
\hline Phase III study of idebenone in (DMD) & December 2011 & 3 & Recruiting & NCTOI027884 \\
\hline \multicolumn{5}{|l|}{ Molecular therapies } \\
\hline \multicolumn{5}{|l|}{ Dystrophin restitution: stop codon read-through } \\
\hline A Phase lla extension study of PTCI 24 in DMD & March 20II & $2 a$ & Terminated & NCT00759876 $14-17$ \\
\hline $\begin{array}{l}\text { A Phase lla study of ataluren (PTCI24) in nonambulatory } \\
\text { patients with nonsense-mutation-mediated D/BMD }\end{array}$ & June 2011 & - & Suspended & NCT01009294 $14-17$ \\
\hline Phase llb study of PTCI24 in D/BMD & December 2009 & $2 / 3$ & Completed & NCT00592553 $14-17$ \\
\hline Phase llb extension study of ataluren (PTCI24) in D/BMD & December 2011 & $2 / 3$ & Terminated & NCT00847379/4-17 \\
\hline $\begin{array}{l}\text { Study of ataluren for previously treated patients } \\
\text { with nmDBMD in the United States }\end{array}$ & July 2012 & 3 & Recruiting & NCT0I247207 \\
\hline $\begin{array}{l}\text { Six month study of gentamicin in DMD } \\
\text { with stop codons }\end{array}$ & July 2009 & 1 & Completed & NCT0045107418 \\
\hline \multicolumn{5}{|l|}{ Dystrophin restitution: exon skipping } \\
\hline $\begin{array}{l}\text { A clinical study to assess the efficacy and safety } \\
\text { of GSK2402968 in subjects with DMD }\end{array}$ & March 20II & 3 & Not yet recruiting & NCTOI2540I9 \\
\hline $\begin{array}{l}\text { Phase II double-blind exploratory study of } \\
\text { GSK2402968 in ambulant subjects with DMD }\end{array}$ & November 201I & 2 & Recruiting & NCT0II53932 \\
\hline $\begin{array}{l}\text { A double-blind, escalating dose, randomized, placebo- } \\
\text { controlled study to assess the pharmacokinetics, } \\
\text { safety, and tolerability of single subcutaneous injections } \\
\text { of GSK2402968 in nonambulant subjects with DMD }\end{array}$ & January 201I & 1 & Recruiting & NCTOI I 28855 \\
\hline Phase I/II study of PRO044 in DMD & September 201I & $1 / 2$ & Recruiting & NCTOI03730919 \\
\hline $\begin{array}{l}\text { Restoring dystrophin expression in DMD: a phase I/II } \\
\text { clinical trial using AVI- } 4658\end{array}$ & March 2009 & $1 / 2$ & Completed & NCTO0I5925020 \\
\hline $\begin{array}{l}\text { Dose-ranging study of AVI- } 4658 \text { to induce dystrophin } \\
\text { expression in selected DMD patients }\end{array}$ & June 2010 & $1 / 2$ & Ongoing & NCT0084459720 \\
\hline
\end{tabular}

Notes: Supporting references and the status of the trials as at December 2010 are indicated.

Abbreviations: DMD, Duchenne muscular dystrophy; BMD, Becker muscular dystrophy. 
directly impacting upon expression of dystrophin or its homologue, utrophin.

\section{Ready-to-use and combination therapies}

Corticosteroids have provided the best treatment option available to DMD patients to date and have also been used in limb girdle and BMDs ${ }^{21-23}$ despite significant side effects and the somewhat limited therapeutic value of these drugs. Corticosteroids stabilize muscle strength, ${ }^{24,25}$ and in the short term, adverse effects were common but not clinically severe. ${ }^{26}$ The use of corticosteroids in DMD is common and has been proposed as the 'gold standard', against which other treatments may be measured, ${ }^{24}$ despite the uncertainty over the mode of action. The benefits of steroids in DMD in the short term have been validated through randomized clinical trials, ${ }^{26,27}$ although dosage regimens are yet to be standardized. Significant impacts on health, quality of life, and health care costs in DMD were reported with the long-term use of deflazacort in uncontrolled cohort studies. ${ }^{2-30}$ Treated boys had significantly better pulmonary and cardiac function and remained ambulant longer than untreated boys. ${ }^{28}$

The combination of steroid administration, respiratory and cardiac management, and physical care have led to dramatic improvements in quality of life, maintenance of function, and longevity in DMD. ${ }^{31}$ DMD children treated by multiple interventions now have a possible life expectancy more than twice than that of those born in the $1960 \mathrm{~s},{ }^{32}$ and the optimism that appropriate combinations of indirect treatments, with restoration, repair, or replacement of functional dystrophin, will dramatically alter the natural history of DMD is justified. With steroids now in common use, it is probable that muscular dystrophy patients being considered as subjects for clinical trials of investigational therapies, including molecular interventions, will be taking, or will have been treated with, corticosteroids. It is imperative to not only identify any contraindications to combination treatment, but also identify agents that might enhance the effects of other interventions.

Apart from corticosteroids, no other validated therapies for DMD have been available, and there is much interest in both nutritional supplements and ready-to-use pharmacological agents to reduce the relentless progression of the disease. The availability of the $m d x$ mouse $^{33,34}$ and golden retriever muscular dystrophy (GRMD) dog $\operatorname{dog}^{35,36}$ dystrophinopathy models has led to extensive preclinical studies on potential therapeutics. However, the lack of standardized experimental end points for the $m d x$ mouse $^{37}$ and phenotypic variation in the dog model, ${ }^{38}$ together with the high cost of maintaining the dogs, have made rigorous comparisons difficult. Evaluation of a number of compounds for the ability to limit the decline in muscle strength in $m d x$ mice by Granchelli et $\mathrm{al}^{39}$ indicated that prednisone, pentoxifylline, Tinset ${ }^{\circledR}$, insulin-like growth factor 1 (IGF-1), glutamine, glutamine plus alanine, and creatinine all improved muscle strength. Subsequent studies have failed to confirm some of these findings, particularly when treatment duration is extended. Implementation of validated preclinical assessment in $m d x$ mice $e^{37,40-42}$ that includes in vivo functional end points and histopathology and biochemical markers will facilitate more rigorous comparison of preclinical data from different laboratories and expedite evaluation in the $m d x$ mouse, leading to effective clinical treatments for DMD. ${ }^{42}$

Although the $m d x$ mouse is an appropriate 'molecular' dystrophinopathy model, its validity as a 'clinical' model for DMD, with its mild dystrophic pathology in muscles other than the diaphragm, is debatable. This has prompted the use of exercised $m d x$ mice, which show a typical pattern of muscle weakness in vivo and exacerbated dystrophic pathology in heart. ${ }^{43}$ Conductance to chloride in $m d x$ muscle is impaired by chronic exercise and responds to treatment with compounds that stimulate regeneration (IGF-1 and steroids) or impede calcium-induced degeneration or inflammation (taurine and steroids). ${ }^{40,41}$ Short-term beneficial effects on dystrophic pathology in $m d x$ mice using a number of agents, including corticosteroids and arginine, have been reported, while chronic, continuous treatment with prednisone showed deleterious effects to skeletal and cardiac muscles, ${ }^{44}$ and arginine leads to fibrosis of dystrophic heart and muscles. ${ }^{45}$ Prednisolone treatment in $m d x$ mice did not affect force loss during eccentric contractions or recovery of force following injury. These data emphasize a limitation of using mice as a preclinical model for DMD, because the increase in muscle strength in boys with DMD and taking prednisolone does not appear to occur via the same mechanism in dystrophic mice. ${ }^{46}$

Payne and colleagues ${ }^{47}$ evaluated the potential benefit from creatine monohydrate, conjugated linoleic acid, alphalipoic acid, and beta-hydroxy-beta-methylbutyrate alone, in combination, and with prednisolone in exercised $m d x$ mice and report evidence of therapeutic benefit from the fourcompound combination therapy alone and together with corticosteroids.

Evidence supporting the essential role of functional ischemia in contraction-induced myofiber damage and a 'two-hit' mechanism in $m d x$ mice was reported by Asai et al. ${ }^{12}$ 
The vasoactive drug tadalafil, a phosphodiesterase type 5 inhibitor, administered to $m d x$ mice ameliorated muscle damage, and this has prompted a study of tadalafil in selected BMD patients (Table 1).

\section{Indirect approaches}

Skeletal muscle mass is dynamic, and under certain environmental cues and conditions, can be increased by different mechanisms or, conversely, reduced through activation of atrophy pathways induced by starvation, unloading, or disease. Hence, opportunities exist for intervention in muscular dystrophies by promoting the addition of new myonuclei into growing or regenerating myofibers, upregulating protein synthesis pathways, or suppressing inflammatory and atrophy pathways.

Myostatin (growth and differentiation factor 8 [GDF8]) has been identified as a major negative regulator of skeletal muscle mass, with myostatin-null animals showing a remarkable increase in mass of some muscles by $200 \%-300 \%$. Myostatin is generated in an inactive form, and two separate proteolytic cleavages first remove the N-terminal signal peptide and then cleave the propeptide domain to produce the active form of the protein. Inhibition of the myostatin pathway represents a promising strategy to influence muscle mass and improves functional outcomes in muscle-wasting conditions (for review see Patel and Amthor ${ }^{48}$ ).

Follistatin is a natural antagonist of myostatin and other members of the transforming growth factor beta (TGF- $\beta$ ) superfamily, and overexpression of follistatin in mouse muscle leads to a profound increase in skeletal muscle mass (for review see Rodino-Klapac et $\mathrm{al}^{49}$ and Rose et $\mathrm{al}^{50}$ ). Disruption of the myostatin signaling pathway by overexpression of follistatin-related gene (FLRG), ${ }^{51}$ GDF-associated serum protein, ${ }^{52}$ and the myostatin propeptide ${ }^{51}$ resulted in substantially improved muscle function and increased mass in both normal and dystrophic tissue. . $^{5,53}$

Myostatin is not the only regulator of muscle growth, and it is apparent that other members of the TGF- $\beta$ superfamily influence muscle mass. Activins are also members of the TGF- $\beta$ family and are structurally related to myostatin. Both activins and myostatin signal through activin type II receptors (ActRIIA and ActRIIB) and their activities are regulated by follistatins and FLRG and by intracellular receptorinteracting proteins by novel mechanisms (for review see Tsuchida ${ }^{54}$ ). ACE-031 is a recombinant, soluble form of the activin receptor composed of the extracellular domain of the ActRIIB receptor and the human immunoglobulin Fc region. ${ }^{13}$ Preclinical studies in the $m d x$ mouse ${ }^{13}$ and studies in normal volunteers were most promising, prompting further development of ACE-031 (see http://clinicaltrials.gov/ct2/ show/NCT00755638). DMD patients are being recruited for a clinical study to determine if ACE-031 is safe and well tolerated in children and to establish an optimal dosage regimen with respect to safety and pharmacodynamic activity (see http://clinicaltrials.gov/ct2/show/NCT01099761). Lee and colleagues ${ }^{55}$ present evidence, suggesting that activin $\mathrm{A}$ may be one of the ligands that is regulated by follistatin and that it functions with myostatin to limit muscle mass.

Contraction-induced injury is a major contributing factor to the pathophysiology of muscular dystrophy, and therapies that attenuate this effect are being explored. ${ }^{56}$ IGF-1 variants mediate growth hormone signaling, and IGF-1 functions and regulation are complex and tissue specific. Mechano-growth factor (MGF) is an alternative splicing variant of IGF-1, and its expression is significantly increased in muscle, bone, and tendon following damage resulting from mechanical stimuli, and in the brain and heart following ischemia. MGF has been shown to activate satellite cells in muscle, resulting in hypertrophy or regeneration (for review see Dai et $\mathrm{al}^{57}$ ). Patients are currently being recruited for a study to determine whether IGF-1 therapy improves or preserves muscle function in DMD (see http://clinicaltrialsfeeds.org/clinical-trials/ show/NCT01207908).

Degradation of skeletal muscle extracellular matrix, inflammation, and fibrosis are the common pathological features in DMD. Although the underlying mechanisms remain poorly understood, strategies to ameliorate dystrophic pathology are being considered. Kumar and colleagues ${ }^{58,59}$ postulated that since expression of various matrix metalloproteinases are increased in dystrophic muscle, their suppression could dampen the extent of muscle pathogenesis in dystrophin deficiency. The 2 -week-old $m d x$ mice received three intraperitoneal injections per week over a 5-week period of batimastat (BB-94), a broad-spectrum peptide inhibitor of matrix metalloproteinases. Compared to sham-treated controls, the BB-94-treated $m d x$ mice were found to have reduced necrosis, infiltration of macrophages, centronucleated fibers, and expression of embryonic myosin heavy chain. Deletion of the $M m p 9$ gene in $m d x$ mice significantly improved muscle regeneration, pathology and function, and reduced muscle injury and inflammation. Pharmacological inhibition of Mmp9 activity also ameliorated skeletal muscle pathogenesis and enhanced myofiber regeneration in $m d x$ mice. ${ }^{59}$

Oxidative stress and in particular, abnormal production of reactive oxygen species in mitochondria by monoamine 
oxidase have been identified as contributing to dystrophic pathogenesis. ${ }^{60}$ Thus, administration of antioxidants could, in theory, be beneficial. Pargyline, a monoamine oxygenase inhibitor, reduced reactive oxygen species accumulation along with a beneficial effect on dystrophic phenotype and muscle strength in mouse muscular dystrophy models, including $m d x$ mice. ${ }^{60}$ Idebenone was cardioprotective and improved exercise performance in the $m d x$ mouse ${ }^{61}$ and has been evaluated in DMD and Friedreich's ataxia patients. Dorchies and colleagues ${ }^{62}$ demonstrated that a green tea polyphenol blend and derived extracts could protect primary $m d x$ muscle cells from oxidative damage induced by hydrogen peroxide by scavenging $\mathrm{H}_{2} \mathrm{O}_{2}$ and by improving the glutathione balance.

Most DMD patients develop clinically significant cardiomyopathy during the second decade of life, and currently, there are no effective therapies for the cardiomyopathy of DMD. Improvements in palliative care and management of respiratory function are extending the lives of patients. Strategies that restore dystrophin in skeletal muscles, but do not result in restitution of cardiac dystrophin expression, are likely to exacerbate this problem. ${ }^{63,64}$ Thus, there is an urgent need to address the emerging heart disease in DMD. Chronic infusion of a membrane-sealing poloxamer 188 (P188) to severely affected dystrophic dogs reduced myocardial fibrosis and prevented left ventricular remodeling. ${ }^{65}$ The P188 is Food and Drug Administration approved for short-term applications in humans and has the potential to halt the progression of dystrophic cardiomyopathy.

Although small molecules may be able to promote muscle growth and membrane stabilization or protect cells from oxidative stress, another approach relies on novel compounds to specifically upregulate expression of a homologous gene. Shortly after the dystrophin gene was identified, Love and coworkers ${ }^{66}$ identified an autosomal gene transcript that showed strong homology to dystrophin. Utrophin, a homologue of dystrophin expressed during fetal development, but restricted to the neuromuscular junction in mature muscle fibers, was subsequently shown to be able to replace dystrophin, if sufficiently overexpressed as a truncated utrophin transgene ${ }^{67}$ and by an adenovirus. ${ }^{68,69}$ Ubiquitous overexpression of utrophin in the $m d x$ mouse was nontoxic, ${ }^{70}$ prompting the search for compounds to reactivate utrophin expression. High-throughput screens identified several lead compounds that were refined and validated before entering a single-center, double-blind, placebo-controlled, singledose escalation study, followed by a multiple-dose escalation study in healthy volunteers, sponsored by BioMarin.
However, it was recently announced that development of BMN 195 (BioMarin Pharmaceutical Inc., Novato, CA) is being discontinued due to 'pharmaceutical and pharmacokinetic challenges'. BioMarin concluded that other approaches to the upregulation of utrophin may be more feasible and are currently developing additional compounds to take forward to early human studies.

\section{Dystrophin restitution therapies}

It is perhaps not too surprising that therapies designed to modulate one or more of the downstream pathogenic pathways resulting from dystrophin deficiency confer only modest or transient benefits. However, such approaches do have merit. Glucocorticoids confer a measurable but transient benefit by delaying the decline in muscle function and are currently regarded as standard in the management of DMD. ${ }^{24,25,32}$ Dystrophin plays a pivotal role in forming a stabilizing link between the actin cytoskeleton and the dystrophin-associated complex of proteins embedded in the sarcolemma, and consequently, the restitution of dystrophin with some degree of function is likely to offer more tangible benefits to DMD muscle.

Apart from dystrophin expression mediated by gene or cell therapies, two distinct strategies to overcome dystrophin mutations have shown great potential in preclinical studies. More than 2 decades ago, particular antibiotics of the aminoglycoside family appeared to promote codon misreading during eukaryotic messenger RNA (mRNA) translation and allow read-through of nonsense mutations (for review see Finkel $\left.{ }^{71}\right){ }^{72}$ The use of gentamicin, one of the first compounds reported to induce read-through of nonsense mutations, provided promising data when applied to nonsense mutations in the cystic fibrosis transmembrane regulator gene. ${ }^{73}$ It is essential that codons encoding amino acids and normal termination codons are correctly processed, as accumulation of mistranslated proteins could be catastrophic. The discrimination of a premature stop codon from a normal stop codon was considered possible, determined by the context of surrounding bases and the fourth base of the termination codon.

Potential renal and otic adverse effects associated with gentamicin exposure are well documented, prompting the search for other compounds to specifically induce readthrough of nonsense mutations. PTC-124 (ataluren; PTC Therapeutics, South Plainfield, NJ) was identified as the lead compound reading through the UGA termination codon. This compound was reported to restore some dystrophin expression in human and $m d x$ mouse cells, carrying nonsense mutations in the dystrophin gene. Subsequent experiments 
indicated that substantial expression was induced after 4 weeks of treatment in the $m d x$ mouse, ${ }^{17}$ with a combined intraperitoneal and oral administration regimen proving most effective.

With this promising preclinical data, and additional phase I studies in healthy volunteers, a double-blind, placebocontrolled phase IIb trial was initiated to evaluate efficacy and safety over a 48-week period. Participants received either a low dose of ataluren $(10,10$, and $20 \mathrm{mg} / \mathrm{kg} / \mathrm{day})$, a high dose $(20,20$, and $40 \mathrm{mg} / \mathrm{kg} /$ day $)$, or placebo. Despite being very well tolerated, with no participants discontinuing the treatment due to adverse effects, the primary end point of change in the 6-minute walk test failed to reach statistical significance during the trial. Ongoing studies of ataluren in DMD patients have been discontinued for the time being, but additional analysis is underway in patient subgroups.

Whatever the final outcome, these studies have made a major contribution to the design and evaluation of trials for DMD therapies and set important efficacy outcomes that are pivotal for subsequent DMD studies. Ataluren evaluation will continue for other conditions, including cystic fibrosis and hemophilia, and this seems most appropriate, considering that these conditions may benefit from modest increases in the target protein, whereas greater expression of dystrophin will be necessary for physiological and clinical improvement.

The mode of small-molecule screening used by researchers to identify read-through compounds has come under scrutiny. Auld and colleagues ${ }^{74,75}$ report that PTC-124 increased the firefly luciferase read-out by posttranslational stabilization rather than read-through of the termination codon. Clearly, additional studies are needed to clarify this issue. Nonsense mutation read-through holds great promise for patients afflicted by a wide range of inherited disorders caused by nonsense codon mutations.

Paradoxically, despite the potentially adverse side effects associated with long-term gentamicin administration and the first short-term gentamicin study failing to detect any clinical benefit, ${ }^{76}$ Malik and colleagues ${ }^{18}$ recently published data from a 6-month open-label trial and unequivocally demonstrated that gentamicin could indeed restore some dystrophin expression in DMD patients carrying nonsense mutations. Two cohorts received daily infusions of gentamicin $(7.5 \mathrm{mg} / \mathrm{kg}$ ) for 2 weeks, and the serum creatine kinase was reduced to about $50 \%$ in the cohort of DMD individuals with nonsense mutations, whereas there was no change in the cohort of DMD participants whose genes had been inactivated by frameshifting deletions. Two additional cohorts received the low dose $(7.5 \mathrm{mg} / \mathrm{kg})$ either weekly or biweekly for 6 months, and dystrophin levels were increased, with the highest levels reaching up to $15 \%$ of normal levels. In this study, there was no apparent influence of the different premature stop codon sequences on read-through efficiency, and one patient appeared to raise antibodies to the novel dystrophin protein. This study both justifies and highlights the need for continued screening for compounds to safely induce readthrough of premature termination codons. During this study, one participant in the cohort receiving biweekly gentamicin infusions inadvertently received four doses that were $125 \%$ of that intended. He suffered transient high-frequency hearing loss and was withdrawn from the study due to protocol requirements. ${ }^{18}$

The unequivocal demonstration of dystrophin restoration in some DMD cases in response to gentamicin treatment has prompted resurged interest into other compounds, which are more efficient at nonsense mutation read-through, as well as having a lower toxicity profile. Nudelman and colleagues ${ }^{77}$ reported in vitro studies of read-through of several different mutations using the aminoglycoside 2 NB54, which was subsequently shown to be far less toxic than gentamicin.

\section{Splice intervention therapy Preclinical studies}

A DMD therapeutic strategy currently gaining considerable momentum is antisense oligomer (AO)-induced splice manipulation, where a DMD-causing mutation is bypassed by targeted exon removal or 'exon skipping'. One or more exons flanking a frameshifting exon rearrangement may be removed to restore the reading frame, or an exon carrying a nonsense mutation can be masked from the splicing machinery so that it is removed from the mature gene transcript. Different mutations across the dystrophin gene will require specific exon-skipping strategies, necessitating potential scores of oligomers. Unlike experimental therapies being evaluated to upregulate a homologous gene ${ }^{78-80}$ or read-through premature stop codons ${ }^{15,17,71}$ (for review see Nelson et $\mathrm{al}^{81}$ ), exon skipping must be regarded as a personalized therapy because of the spread of different mutations across the dystrophin gene, requiring different exon-skipping strategies. DMD is considered an 'orphan disease', based on the criteria that there are $<200,000$ affected individuals in the USA, and there is little incentive to the private sector to develop and market specific therapies. Bringing any drug to the clinic is costly and challenging, and orphan disease status provides incentives to develop treatments for rare conditions. However, when one considers that scores of different AOs would be 
needed to treat DMD patients with different mutations, the challenges seem insurmountable. Fundamental changes to the drug development pipeline will have to be implemented before exon-skipping therapy can become a reality for all amenable DMD mutations.

There was a flurry in interest in the use of short, chemically synthesized oligomers to modify gene expression after Zamecnik and Stephenson ${ }^{82}$ described the use of an oligodeoxribonucleotide (ODN) to suppress viral replication. Many subsequent reports of gene suppression were eventually attributed to nonsequence-specific effects, often relating to the oligomer backbone. However, as new generation oligomer chemistries were developed and experimental design was refined and became more rigorous, additional methodologies to manipulate gene expression using AOs were developed, including translation suppression, gene silencing and modification of pre-mRNA splicing (for review see Bennett and Swayze $\left.{ }^{83}\right)$.

Manipulation of pre-mRNA splicing can alter gene expression by downregulating the transcript or induce specific isoforms and suppress abnormal or cryptic splicing. A major advantage in assessing changes in pre-mRNA processing is the appearance of a novel transcript, which may be monitored in a positive assay by reverse transcriptase polymerase chain reaction (RT-PCR), or detection of an induced protein by Western blotting. Gene suppression by RNAseH, silencing, or translational blockade can be more problematic to assess because the disappearance or reduction in abundance of a transcript or protein is measured in a negative assay. Absence of evidence, the decreased abundance of a gene transcript or product, is not necessarily irrefutable evidence of absence, as off-target effects of the oligomer may compromise global transcription or translation.

One surprising observation was the high proportion of splice-switching AOs, approximately two-thirds, that did induce some degree of exon skipping. ${ }^{84,85}$ Approximately, one-third of splice-switching AOs initially designed failed to induce any detectable effect on dystrophin pre-mRNA processing and may be considered as 'unintentional' negative controls, despite being complementary to the dystrophin pre-mRNA.

An appropriately designed splice-switching oligomer should induce specific exon skipping and generate a novel mRNA transcript in a dose-dependent manner. If the loss of the targeted exon bypasses a protein-truncating mutation, a new protein should be generated. Mindful of omissions in early AO design, a series of splice-switching oligomer controls, including random, scrambled, unrelated, and sense strand sequences, have been evaluated to confirm that any detectable changes in gene expression were sequence specific and not attributable to the oligomer chemistry or nonsequence-specific effects. ${ }^{85-88}$ However, the concept of exon skipping is now so well established that the majority of recent reports on dystrophin splice switching do not include random, scrambled, or sense oligomer sequences as negative controls. ${ }^{89-93}$

There is little doubt that targeted exon skipping, assuming it can be induced at adequate efficiency in dystrophic muscle, would reduce the severity of most cases of DMD. The reading frame rule holds true in the majority of dystrophin mutations, ${ }^{6}$ with any discordance between the genotype and phenotype normally resolved by studying the dystrophin mRNA and identifying secondary effects on RNA processing as a consequence of the mutation. ${ }^{8}$ Ginjaar and colleagues ${ }^{7}$ identified a nonsense mutation in dystrophin exon 29 in one BMD family that induced different levels of exon skipping in three affected boys. The phenotypes in this family varied from healthy to severely affected and appeared to correlate with the amount of exon 29 skipping, since the loss of this exon does not disrupt the reading frame and removes the mutation. Characterization of the dystrophin gene structure in mildly affected or asymptomatic BMD individuals provides templates for functional dystrophin isoforms and establishes which regions of the protein are partially redundant., ${ }^{9,94-96}$ Furthermore, exon skipping has been shown to occur naturally, as evidenced by the presence of revertant dystrophin-positive fibers in many DMD individuals ${ }^{97}$ and mouse ${ }^{98}$ and canine ${ }^{99}$ models of muscular dystrophy. Although occurring at a frequency too low to be of any substantial clinical benefit, these fibers may contribute to the immune tolerance of induced BMD-like dystrophin isoforms. ${ }^{100}$

The successful implementation of exon skipping to treat DMD will require careful optimization of oligomer design, evaluation, and delivery, and then perhaps even more challenging will be establishment of a product development pipeline to bring new compounds to the clinic.

\section{Splice-switching oligomers Sequence selection}

The application of AOs to induce targeted dystrophin exon skipping was first reported by Takeshima and colleagues, ${ }^{101}$ after detailed characterization of an intraexonic deletion of 52 bp in dystrophin exon 19, which left the acceptor and donor splice sites intact but resulted in the loss of the entire exon. In a series of experiments using different oligomer chemistries and in vitro assessment systems, specific removal 
exon 19 was induced from the dystrophin mRNA in artificial constructs, ${ }^{101}$ lymphoblastoid cells, ${ }^{102}$ and later in human and mouse cells. ${ }^{86}$

Early splice-switching studies in the $m d x$ mouse model of muscular dystrophy targeted the obvious splice sites at the intron 22:exon 23 (acceptor or $3^{\prime}$ ) and exon 23:intron 23 (donor or $5^{\prime}$ ) splice sites, as these motifs offered easily defined and crucial motifs involved in pre-mRNA processing. ${ }^{103,104}$ Although the donor splice site proved to be a most amenable target for exon 23 skipping, the acceptor site was unresponsive, indicating a limitation to directing AOs to obvious splice motifs. ${ }^{104}$ When designing AOs to other dystrophin exons, we chose an empirical approach, starting with the obvious donor and acceptor splice sites and then intraexonic motifs, potential exon splicing enhancers that are predicted binding sites for the SR proteins involved in exon definition. ${ }^{105,106}$

Several hundred AOs have now been designed to the dystrophin pre-mRNA ${ }^{84,85}$ (Wilton and Fletcher, unpublished data), and the mechanisms by which antisense sequences influence exon recognition and splicing have still not been clearly defined. Aartsma-Rus and colleagues ${ }^{107}$ suggest that intraexonic sequences provide better targets that splice sites and proposed that the higher GC content of the exons offered better thermodynamic properties. These authors concluded that 'when designing AOs to induce exon skipping in DMD, targeting exonic sequences is most likely to result in an effective AO. There are, however, exceptions, and of course, further optimization of the AO is often required'.

It is unlikely that a simple formula or set of thermodynamic parameters will guarantee design of effective spliceswitching AOs, as there is considerable variation in levels of induced exon skipping, both within and between exons. AO length and target sequence were identified as important parameters in AO design, ${ }^{108}$ while Wee and colleagues ${ }^{109}$ reported that cotranscriptional pre-mRNA folding influenced AO-induced dystrophin exon skipping. Secondary structures were predicted, and the frequency and localization of base-paired nucleotides in an AO target site correlated with AO performance of $94 \%$ of 176 previously reported sequences. ${ }^{109}$

In a comparative study of several different AOs to induce human dystrophin exon 51 skipping, targeting the donor splice site proved ineffective, despite extensive micro-walking and variation in AO length. ${ }^{110}$ The exons that were difficult to remove using single AOs could often be excised by select $\mathrm{AO}$ combinations, ${ }^{111}$ suggesting that many factors are involved in exon recognition and splicing. Clearly, an oligomer preparation that can induce pronounced exon skipping in cultured cells at $5 \mathrm{nM}$ will be more effective than an oligomer that promotes weak exon removal after transfection at higher concentrations. ${ }^{111}$ Clinical application will require AOs that are effective at low dosages, thus reducing treatment costs and the likelihood of adverse effects, and to date, in vitro evaluation has been widely used to select $\mathrm{AO}$ sequences for dystrophin exon skipping. It was recently reported that in vitro evaluation of novel AOs reflected in vivo exon-skipping activity, at least in the mouse. ${ }^{112}$

Despite strong homology in the dystrophin genes of human, mouse, and dog, directing AOs to the pre-mRNA motifs does not necessarily induce comparable exon skipping. Although the mouse dystrophin exon 23 was readily removed after targeting the donor splice site, the human equivalent was unresponsive. ${ }^{113}$ In this study of comparable exons in human and mouse exon skipping, only one-third of targets were optimal in both species. Similarly, Saito and colleagues $^{93}$ reported that motifs targeted to excise canine dystrophin exons 6 and 8 were also effective in cells from a DMD patient missing exon 7 , although it should be noted that there was a difference in removal of exon 9 between the two species.

\section{Evaluation and quantitation of AO-induced exon skipping}

In order to assess $\mathrm{AO}$ efficacy, it will be important to accurately determine changes in dystrophin expression and restoration of the induced dystrophin isoform synthesis. Ultimately, it will be the amount of dystrophin expression in vivo that will alter the progression of DMD, rather than experimentally enhanced exon skipping assessed by RT-PCR. We previously reported that manipulating RT-PCR amplification conditions exaggerates apparent exon skipping and does not reflect protein levels. ${ }^{114}$ By increasing the cycle number and minimizing the length of the amplicons, $25 \%$ of the transcripts in treated $m d x$ samples appeared to be missing the target exon, yet no dystrophin was detected by Western blotting.

A series of techniques to quantify exon skipping levels by RT-PCR were reported by Spitali and colleagues ${ }^{115}$ and indicated that quantification of small primary PCR products using a bioanalyzer or densitometric analysis generated data close to that from a digital array. Perhaps more relevant to the assessment of exon skipping and dystrophin-isoform restoration in preclinical and clinical studies is the quantification of protein levels in muscle biopsies based upon digital capture of immunofluorescently labeled sections. ${ }^{116}$ 
This method will be of great value in allowing comparative quantification of sarcolemmal proteins, as it allows both abundance and localization of the protein to be monitored. This will be useful in assessing experimental therapies where only partial restoration of the protein may occur. Efforts are now under way to ensure standardized testing in order that data from different clinical trials and different centers can be compared and directly evaluated. ${ }^{117}$ This will be relevant for not only exon skipping, but also other therapies designed to supplement, compensate for, or replace dystrophin.

\section{Oligomer chemistries}

Several different oligomer chemistries have demonstrated some capacity to redirect dystrophin pre-mRNA processing, including DNA oligomers on a phosphorothioate backbone (ODN), ${ }^{102}$ locked nucleic acids, ${ }^{118}$ ethylene nucleic acids, ${ }^{119}$ peptide nucleic acids, ${ }^{92}$ RNA-like analoges with 2'-O-modified bases on a phosphorothioate backbone (2-OMeAO), and phosphorodiamidate morpholino oligomers (PMOs). ${ }^{118,120,121}$ Each oligomer chemistry has specific advantages and limitations and, to date, three different clinical trials have been reported using ODN, 2-OMeAO, and PMOs. ${ }^{19,20,122}$ Active and recently completed clinical trials for DMD listed at http://clinicaltrials.gov are summarized in Table 1.

\section{Delivery}

All nucleic acid therapies are hampered to some extent by limitations of delivery and distribution, and in the case of $\mathrm{DMD}$, it is further complicated by the need to deliver therapeutic levels of the oligomer to skeletal (30\% of total body mass), cardiac, and smooth muscles and other tissues. AO design and evaluation in vitro require transfection with either high concentrations of the compound, as uptake is poor, or the use of a delivery agent to enhance delivery. A large number and variety of reagents have been used to deliver charged AOs in vitro, including cationic liposomes, ${ }^{87,88,104}$ PEI, ${ }^{123}$ copolymers, ${ }^{124,125}$ cationic nanoparticles, ${ }^{126}$ or polymersomes. ${ }^{127}$ Uncharged PMOs are largely ineffective in vitro unless applied at high concentrations with scrape loading, ${ }^{128}$ although delivery can be greatly enhanced with the use of a sense strand leash and a cationic lipoplex ${ }^{121}$ or coupling to cell-penetrating peptides (CPPs) $)^{129-133}$ or an octaguanidine dendrimer. ${ }^{134,135}$ Although many delivery reagents have facilitated $\mathrm{AO}$ uptake in vitro, most will not be applicable to preclinical evaluation or in the clinic. Fortunately, we observed that uncomplexed PMOs were efficiently taken up in the dystrophic muscle after direct intramuscular injection and restored robust dystrophin expression around the injection site. ${ }^{120}$

\section{Animal models}

Exon skipping has now been applied to several animal models, most commonly the $m d x$ mouse that carries a nonsense mutation in exon 23. Although this is not a good clinical model for DMD, it has allowed numerous studies assessing oligomer sequences and chemistries, ${ }^{87,88,112,120,129,133,136-138}$ modifications to enhance PMO uptake, ${ }^{130-132,134,139-141}$ delivery routes, ${ }^{142}$ and regimens. ${ }^{130,139,143,144}$ Other mouse models studied to date include the $m d x^{4 \mathrm{CV}}$ mouse (nonsense mutation in exon 53 that requires removal of exons 52 and 53) $)^{145}$ and the $m d x 52$ mouse missing exon $52 .{ }^{89}$ These latter animal models are perhaps more relevant than the original $m d x$ mouse model, since the mutations occur in the major human deletion hotspot region of the dystrophin gene.

The 'humanized' mouse ${ }^{146}$ contains a complete copy of the human $D M D$ gene integrated into chromosome 5 and has been promoted for the preclinical screening of humanspecific oligomers and comparison of different $\mathrm{AO}$ sequences and chemistries. While the $m d x$ mouse does not reflect clinical severity of DMD and the humanized mouse has a human dystrophin gene processed with rodent splicing machinery, perhaps the most appropriate and challenging animal model in which to test exon skipping as a therapy is the $d k o$ mouse. ${ }^{147}$ Although the utrophin or dystrophin null animals appear normal, especially during the early life, the loss of both genes results in animals with severe muscle wasting, and the $d k o$ animals typically die by the age of 15 weeks. Repeated, weekly, intraperitoneal administration of a PMO conjugated to a cell penetrating peptide (CPP-PMO), starting a few days after birth, was found to prevent onset of pathology. ${ }^{148}$ Treated animals remain normal in appearance at 1 year of age (Goyenvalle, personal communication), demonstrating that the restoration of a BMD-like dystrophin isoform in this model is highly functional.

In vivo studies using the GRMD canine model were reported by Yokota and colleagues ${ }^{149}$ after systemic administration of substantial amounts of a PMO cocktail to excise exons 6 and 8/9 to restore the reading frame around the exon 7 frameshift. This work was particularly encouraging in that large amounts of PMO were administered without any obvious adverse effects, and dystrophin was expressed throughout the body. Like other studies using similar dosages of uncomplexed PMOs in the mouse, ${ }^{120,136}$ dystrophin expression in the heart was low or undetectable, presumably reflecting limitations of uptake; however, systemic 
administration of a single dose of an uncomplexed PMO at $3 \mathrm{~g} / \mathrm{kg}$ resulted in dystrophin restitution in skeletal and cardiac muscles in the $m d x$ mouse, without clear toxicity. ${ }^{144}$ Efficient AO delivery into many tissues, including the heart, may also be addressed by the use of specific CPPs coupled to the PMO. ${ }^{130}$ These researchers recently reported long-term prevention ( 7 months) of cardiac dysfunction after early treatment with a CPP-PMO. ${ }^{139}$ Other CPPs for enhanced PMO delivery have been reported, ${ }^{141,150,151}$ and this promises to be a most active area of research. Although many CPPs examined to date greatly enhance PMO uptake, concerns remain regarding the clinical applicability of these compounds due to potential adverse effects.

\section{Clinical trials}

The first splice-switching clinical trial in a 10 -year-old, nonambulant DMD patient used systemic administration of a 31 mer ODN on a phosphorothioate backbone, designed to excise exon 19 and restore the reading frame around the DMD-causing exon 20 deletion. ${ }^{152}$ Although dystrophin exon 19 skipping was demonstrated in RNA extracted from lymphocytes after the infusion, the dystrophin staining was equivocal, and Western blot data was not presented. The inconclusive dystrophin staining in this $n=1$ study may be attributed to several factors, including a readily available but less-than-optimal oligomer chemistry or insufficient dosage and duration of treatment to restore detectable dystrophin expression. Although this trial did not generate unequivocal dystrophin expression or demonstrate any benefit to the recipient, there were no adverse effects, and the compounds were reported to be well tolerated. ${ }^{152}$ ODNs are typically used to downregulate gene expression through induction of RNAseH, a ubiquitous enzyme that degrades the RNA strand of an RNA:ODN duplex. ${ }^{153}$ We previously demonstrated that ODNs induce dystrophin exon 19 skipping, ${ }^{86}$ but only after in vitro transfection at much higher concentrations than those used for the same sequence prepared as a $2 \mathrm{OMe} \mathrm{AO}$ or PMO. Although $\mathrm{RNaseH}$ is found in the nucleus where the AO splice switching occurs during cotranscriptional processing, presumably once the target exon is excised from the mature mRNA, that transcript would no longer be susceptible to RNaseH degradation.

In contrast, proof-of-concept studies using AOs of 2OMe or PMO chemistries conclusively demonstrated that induced exon 51 skipping restored the dystrophin reading frame around amenable DMD deletions and restored dystrophin expression after localized delivery. Van Deutekom and colleagues ${ }^{19}$ reported the administration of PRO051, a synthetic 20 mer composed of 2'-O-methyl modified bases, on a phosphorothioate backbone designed to excise exon 51 during dystrophin pre-mRNA processing in patients with deletions of exon 50, 48-50, 49-50, and 52. After injection of $0.8 \mathrm{mg}$ of PRO051 into the tibialis anterior muscle, a biopsy was taken 28 days later and found to contain a high proportion of dystrophin-positive fibers. It was reported that accurate quantification of skipping efficiencies and the meaningful correlation between levels of RNA and protein were not possible since high-sensitivity RT-PCR conditions were employed. Nevertheless, results were sufficiently encouraging to proceed with systemic administration of PRO051, delivered subcutaneously at a weekly dose of $6 \mathrm{mg} / \mathrm{kg}$ for several months. Tantalizing unpublished data has been reported, indicating low-level, widespread dystrophin expression after 12 weeks of treatment, and peer-reviewed published data is eagerly awaited.

We proposed that the PMO chemistry is better suited for clinical application for induced exon skipping because of the sustained exon skipping in vivo. ${ }^{120,129}$ In addition, PMOs, developed to suppress translation, ${ }^{154}$ have been developed as antivirals, ${ }^{155,156}$ and in a number of clinical trials, they have shown an excellent safety profile. ${ }^{157,158}$

Analysis of DMD deletion frequency has indicated that exclusion of exon 51 will benefit the greatest number of DMD patients, and this exon was selected as the lead target exon for therapeutic exon-skipping trials. After comparative evaluation of several PMO sequences, including PRO051, one was selected for further preclinical development. ${ }^{110}$ This compound, licensed through the University of Western Australia to AVI BioPharma (Bothell, WA) was designated AVI-4658 and used in a single-blind, placebo-controlled, dose-escalation study, sponsored by the MDEX consortium, to confirm proof-of-concept that DMD mutations could be bypassed using a PMO. ${ }^{20}$ The MDEX trial structure differed from the PRO051 study in that low $(0.09 \mathrm{mg})$ or high $(0.9 \mathrm{mg})$ doses were administered into the extensor digitorum brevis of one foot, while a sham (saline) injection was applied to the contralateral muscle. An open biopsy of both muscles was performed 3-4 weeks later, and samples were subjected to RT-PCR and immunohistochemical studies. There was a clear dose response. Dystrophin exon 51 skipping was detected in the muscle receiving the low dose, but no protein was evident under preestablished testing conditions. At the high dose, exon 51 skipping was readily detected by RT-PCR in test biopsies from all participants, and there was unequivocal dystrophin expression as determined by Western blotting and immunofluorescent staining. ${ }^{20}$ 
The preliminary results from the AVI-4658 study were sufficiently encouraging to commence dose-escalating systemic administration in DMD participants, whose genomic deletions would have the reading frame restored by exon 51 exclusion (Table 1). Participants were divided into 6 cohorts, each receiving 12, once-weekly, intravenous infusions of AVI-4658 at doses of 0.5, 1, 2, 4, 10, and $20 \mathrm{mg} / \mathrm{kg}$ (Muntoni, personal communication). Data indicate that exon skipping was induced in dose-dependent manner, and apart from one individual receiving $2 \mathrm{mg} / \mathrm{kg}$ who was found to be a 'strong' responder, all other participants receiving up to $4 \mathrm{mg} / \mathrm{kg}$ had transcripts missing exon 51, but protein was not detected. All boys receiving 10 or $20 \mathrm{mg} / \mathrm{kg}$ showed strong exon skipping by RT-PCR, and dystrophin expression was readily detectable in three out of four boys in each cohort. One boy from each of these cohorts had considerably higher dystrophin expression than the others who were deemed to be 'strong responders'. In summary, seven patients had unequivocally increased dystrophin expression after comparing pre- and posttreatment biopsies (Muntoni, personal communication). An extension to the MDEX study has not been offered to the participants at this stage (see http://www.actionduchenne.org/duchennepedia/article/229/ recent-avi-4658-trial-results-), which is unfortunate considering the positive outcomes in terms of dystrophin expression at the higher doses of AVI-4658. One of the most attractive features of the PMO chemistry is that these compounds appear to be very well tolerated, with no PMO-related effects on cardiovascular, respiratory, global neurological, renal, or liver parameters after administration of the maximum feasible dose $(320 \mathrm{mg} / \mathrm{kg})$ in cynomolgus monkeys. ${ }^{159}$ Both the mouse and the canine models of muscular dystrophy have received different PMOs at substantial dosages of $200 \mathrm{mg} / \mathrm{kg}$ in the GRMD animal ${ }^{149}$ and $3 \mathrm{gm} / \mathrm{kg}$ in the $m d x$ mouse. ${ }^{144}$ Dystrophin expression was restored without overt toxicity; however, the consequences of long-term exposure at these dosages are yet to be established.

Furthermore, while high PMO doses may offer a rapid restitution of dystrophin synthesis, it is most unlikely that, even if these high doses were to prove safe and tolerable, such amounts would be financially sustainable at this time. Until recently, patent protection on morpholino synthesis restricted the production of Good Laboratory Practicecompliant PMOs, and production facilities at this point in time are limited. Potential manufacturers would be reluctant to commit to major capital expenditure on expanded production facilities, especially when there is no guaranteed demand. Although the PMO exon-skipping trials are generating exceedingly positive data, no obvious clinical benefit has yet been conferred to any participant, and future requirements for these conpounds are uncertain at this time.

Nevertheless, PMO production is a technical issue. Those involved in early molecular biology experiments may recall the high cost of oligomers used as gene-specific probes or for PCR. Not only has the quality and reliability of production increased, but also costs have decreased by orders of magnitude. In some respects, there are many similarities to the development of penicillin, where the first reported US patient treated for streptococcal septicemia used one half of the total available supply produced by Merck \& Co (Whitehouse Station, NJ). ${ }^{160}$ At that time, penicillin was priceless, and 15 months later, there was only enough material to treat 10 patients (see http://www.lib.niu.edu/2001/iht810139.html). However, in response to demand to treat casualties from World War II, there was a concentrated effort to increase production, and by 1946 , the cost was reported as $55 \mathrm{c}$ per dose.

\section{Concluding remarks}

In treating DMD, significant long-term benefit can only be conferred by dystrophin restitution, and of all the novel experimental therapies to treat DMD discussed here, only gentamicin administration and oligomer-induced exon skipping have resulted in readily detectable dystrophin expression in DMD patient's muscle. ${ }^{18-20}$ Although gentamicin treatment has produced promising results, its use can be accompanied by significant side effects that may limit long-term administration. Nonsense mutation read-through is restricted to the $10 \%$ of cases caused by premature termination codons, but it is potentially applicable to a similar percentage of a wide range of inherited disorders. This data, together with the broad applicability of read-through compounds, would be expected to accelerate development of these drugs and the search for compounds with improved safety profiles.

The promising clinical data from the DMD exon-skipping trials is anticipated to drive further development in this field, particularly for the relatively small number of spliceswitching compounds required to treat the more common DMD mutations, but many compounds must be designed and optimized to address all amenable mutations, so as not to disadvantage DMD patients with the added misfortune of having rare mutations. Although the greatest benefit of dystrophin restitution will undoubtedly be derived from early treatment in younger patients, the use of emerging 'combination' therapies that aim to preserve muscle or promote muscle repair in muscular dystrophies and restore protein expression ${ }^{161}$ may well deliver functional improvements in older patients. 


\section{Acknowledgments}

The authors acknowledge funding from National Institutes of Health USA, the Muscular Dystrophy Association of the United States of America, Muscular Dystrophy Western Australia, the National Health and Medical Research Council of Australia, the James and Matthew Foundation, the Gavriel Meir Trust and the Medical and Health Research Infrastructure Fund, Western Australia.

\section{Disclosure}

The authors report no conflicts of interest in this work.

\section{References}

1. Emery AE. The muscular dystrophies. Lancet. 2002;359(9307): 687-695.

2. Love DR, Byth BC, Tinsley JM, Blake DJ, Davies KE. Dystrophin and dystrophin-related proteins: a review of protein and RNA studies. Neuromuscul Disord. 1993;3(1):5-21.

3. Bakker E, Veenema H, Den Dunnen JT, et al. Germinal mosaicism increases the recurrence risk for 'new' Duchenne muscular dystrophy mutations. J Med Genet. 1989;26(9):553-559.

4. Koenig M, Beggs AH, Moyer M, et al. The molecular basis for Duchenne versus Becker muscular dystrophy: correlation of severity with type of deletion. Am J Hum Genet. 1989;45(4):498-506.

5. Koenig M, Hoffman EP, Bertelson CJ, Monaco AP, Feener C, Kunkel LM. Complete cloning of the Duchenne muscular dystrophy (DMD) cDNA and preliminary genomic organization of the DMD gene in normal and affected individuals. Cell. 1987;50(3): 509-517.

6. Monaco AP, Bertelson CJ, Liechti-Gallati S, Moser H, Kunkel LM. An explanation for the phenotypic differences between patients bearing partial deletions of the DMD locus. Genomics. 1988;2(1):90-95.

7. Ginjaar IB, Kneppers AL, v d Meulen JD, et al. Dystrophin nonsense mutation induces different levels of exon 29 skipping and leads to variable phenotypes within one BMD family. Eur J Hum Genet. 2000;8(10): 793-796.

8. Aartsma-Rus A, van Deutekom JC, Fokkema IF, van Ommen GJ, Den Dunnen JT. Entries in the Leiden Duchenne muscular dystrophy mutation database: an overview of mutation types and paradoxical cases that confirm the reading-frame rule. Muscle Nerve. 2006;34(2): 135-144.

9. England SB, Nicholson LV, Johnson MA, et al. Very mild muscular dystrophy associated with the deletion of $46 \%$ of dystrophin. Nature. 1990;343(6254):180-182.

10. Folkers K, Simonsen R. Two successful double-blind trials with coenzyme Q10 (vitamin Q10) on muscular dystrophies and neurogenic atrophies. Biochim Biophys Acta. 1995;1271(1):281-286.

11. Vandenburgh H, Shansky J, Benesch-Lee F, et al. Automated drug screening with contractile muscle tissue engineered from dystrophic myoblasts. FASEB J. 2009;23(10):3325-3334.

12. Asai A, Sahani N, Kaneki M, Ouchi Y, Martyn JA, Yasuhara SE. Primary role of functional ischemia, quantitative evidence for the two-hit mechanism, and phosphodiesterase-5 inhibitor therapy in mouse muscular dystrophy. PLoS One. 2007;2(8):e806.

13. Cadena SM, Tomkinson KN, Monnell TE, et al. Administration of a soluble activin type IIB receptor promotes skeletal muscle growth independent of fiber type. J Appl Physiol. 2010;109(3): 635-642.

14. Hamed SA. Drug evaluation: PTC-124 - a potential treatment of cystic fibrosis and Duchenne muscular dystrophy. IDrugs. 2006;9(11): 783-789.
15. Hirawat S, Welch EM, Elfring GL, et al. Safety, tolerability, and pharmacokinetics of PTC124, a nonaminoglycoside nonsense mutation suppressor, following single- and multiple-dose administration to healthy male and female adult volunteers. J Clin Pharmacol. 2007;47(4): 430-444.

16. Welch E, Goetz D, Almstead N. Reading through premature stop codons with PTC1 24. Project Catalyst to find more Duchenne drugs. Interview by Guenter Scheuerbrandt. Acta Myol. 2008;27:63-68.

17. Welch EM, Barton ER, Zhuo J, et al. PTC124 targets genetic disorders caused by nonsense mutations. Nature. 2007;447(7140):87-91.

18. Malik V, Rodino-Klapac LR, Viollet L, et al. Gentamicin-induced readthrough of stop codons in Duchenne muscular dystrophy. Ann Neurol. 2010;67(6):771-780.

19. Van Deutekom JC, Janson AA, Ginjaar IB, et al. Local dystrophin restoration with antisense oligonucleotide PRO051. N Engl J Med. 2007;357(26):2677-2686.

20. Kinali M, Arechavala-Gomeza V, Feng L, et al. Local restoration of dystrophin expression with the morpholino oligomer AVI-4658 in Duchenne muscular dystrophy: a single-blind, placebo-controlled, dose-escalation, proof-of-concept study. Lancet Neurol. 2009;8(10): 918-928.

21. Matthews DJ, James KA, Miller LA, et al; MD STARnet. Use of corticosteroids in a population-based cohort of boys with Duchenne and Becker muscular dystrophy. J Child Neurol. 2010;25(11): 1319-1324.

22. Hussein MR, Hamed SA, Mostafa MG, Abu-Dief EE, Kamel NF, Kandil MR. The effects of glucocorticoid therapy on the inflammatory and dendritic cells in muscular dystrophies. Int J Exp Pathol. 2006; 87(6):451-461.

23. Darin N, Kroksmark AK, Ahlander AC, Moslemi AR, Oldfors A, Tulinius M. Inflammation and response to steroid treatment in limbgirdle muscular dystrophy 2I. Eur J Paediatr Neurol. 2007;11(6): 353-357.

24. Angelini C. The role of corticosteroids in muscular dystrophy: a critical appraisal. Muscle Nerve. 2007;36(4):424-435.

25. Bushby K, Muntoni F, Urtizberea A, Hughes R, Griggs R. Report on the 124th ENMC International Workshop. Treatment of Duchenne muscular dystrophy; defining the gold standards of management in the use of corticosteroids. April 2-4, 2004; Naarden, The Netherlands. Neuromuscul Disord. 2004;14(8-9):526-534.

26. Manzur AY, Kuntzer T, Pike M, Swan A. Glucocorticoid corticosteroids for Duchenne muscular dystrophy. Cochrane Database Syst Rev. 2004; 2:CD003725.

27. Bushby K, Griggs R; MSG/ENMC FOR DMD Trial Study Group. 145th ENMC International Workshop: planning for an International Trial of Steroid Dosage Regimes in DMD (FOR DMD), October 22-24, 2006; Naarden, The Netherlands. Neuromuscul Disord. 2007;17(5): 423-428.

28. Biggar WD, Harris VA, Eliasoph L, Alman B. Long-term benefits of deflazacort treatment for boys with Duchenne muscular dystrophy in their second decade. Neuromuscul Disord. 2006;16(4):249-255.

29. Biggar WD, Politano L, Harris VA, et al. Deflazacort in Duchenne muscular dystrophy: a comparison of two different protocols. Neuromuscul Disord. 2004;14(8-9):476-482.

30. Silversides CK, Webb GD, Harris VA, Biggar DW. Effects of deflazacort on left ventricular function in patients with Duchenne muscular dystrophy. Am J Cardiol. 2003;91(6):769-772.

31. Eagle M, Baudouin SV, Chandler C, Giddings DR, Bullock R, Bushby K. Survival in Duchenne muscular dystrophy: improvements in life expectancy since 1967 and the impact of home nocturnal ventilation. Neuromuscul Disord. 2002;12(10):926-929.

32. Bushby K, Bourke J, Bullock R, Eagle M, Gibson M, Quinby J. The multidisciplinary management of Duchenne muscular dystrophy. Curr Paediatr. 2005;15(4):292-300.

33. Bulfield G, Siller WG, Wight PA, Moore KJ. X chromosome-linked muscular dystrophy (mdx) in the mouse. Proc Natl Acad Sci U S A. 1984;81(4):1189-1192. 
34. Sicinski P, Geng Y, Ryder-Cook AS, Barnard EA, Darlison MG, Barnard PJ. The molecular basis of muscular dystrophy in the mdx mouse: a point mutation. Science. 1989;244(4912):1578-1580.

35. Sharp NJ, Kornegay JN, van Camp SD, et al. An error in dystrophin mRNA processing in golden retriever muscular dystrophy, an animal homologue of Duchenne muscular dystrophy. Genomics. 1992;13(1): $115-121$

36. Kornegay JN, Tuler SM, Miller DM, Levesque DC. Muscular dystrophy in a litter of golden retriever dogs. Muscle Nerve. 1988;11(10): 1056-1064.

37. Spurney CF, Gordish-Dressman H, Guerron AD, et al. Preclinical drug trials in the mdx mouse: assessment of reliable and sensitive outcome measures. Muscle Nerve. 2009;39(5):591-602.

38. Ambrósio CE, Valadares MC, Zucconi E, et al. Ringo, a Golden Retriever Muscular Dystrophy (GRMD) dog with absent dystrophin but normal strength. Neuromuscul Disord. 2008;18(11):892-893.

39. Granchelli JA, Pollina C, Hudecki MS. Pre-clinical screening of drugs using the mdx mouse. Neuromuscul Disord. 2000;10(4-5):235-239.

40. Cozzoli A, Rolland JF, Capogrosso RF, et al. Evaluation of potential synergistic action of a combined treatment with alpha-methyl-prednisolone and taurine on the mdx mouse model of Duchenne muscular dystrophy. Neuropathol Appl Neurobiol. July 1, 2010. [Epub ahead of print].

41. De Luca A, Pierno S, Liantonio A, et al. Enhanced dystrophic progression in $\mathrm{mdx}$ mice by exercise and beneficial effects of taurine and insulin-like growth factor-1. J Pharmacol Exp Ther. 2003;304(1): 453-463.

42. Grounds MD, Radley HG, Lynch GS, Nagaraju K, de Luca A. Towards developing standard operating procedures for pre-clinical testing in the mdx mouse model of Duchenne muscular dystrophy. Neurobiol Dis. 2008;31(1):1-19.

43. Nakamura A, Yoshida K, Takeda S, Dohi N, Ikeda S. Progression of dystrophic features and activation of mitogen-activated protein kinases and calcineurin by physical exercise, in hearts of $\mathrm{mdx}$ mice. FEBS Lett. 2002;520(1-3):18-24.

44. Bauer R, Straub V, Blain A, Bushby K, MacGowan GA. Contrasting effects of steroids and angiotensin-converting-enzyme inhibitors in a mouse model of dystrophin-deficient cardiomyopathy. Eur J Heart Fail. 2009;11(5):463-471.

45. Wehling-Henricks M, Jordan MC, Gotoh T, Grody WW, Roos KP, Tidball JG. Arginine metabolism by macrophages promotes cardiac and muscle fibrosis in mdx muscular dystrophy. PLoS One. 2010; 5(5):e10763.

46. Baltgalvis KA, Call JA, Nikas JB, Lowe DA. Effects of prednisolone on skeletal muscle contractility in $\mathrm{mdx}$ mice. Muscle Nerve. 2009; 40(3):443-454.

47. Payne ET, Yasuda N, Bourgeois JM, et al. Nutritional therapy improves function and complements corticosteroid intervention in $\mathrm{mdx}$ mice. Muscle Nerve. 2006;33(1):66-77.

48. Patel K, Amthor H. The function of Myostatin and strategies of Myostatin blockade-new hope for therapies aimed at promoting growth of skeletal muscle. Neuromuscul Disord. 2005;15(2):117-126.

49. Rodino-Klapac LR, Haidet AM, Kota J, Handy C, Kaspar BK, Mendell JR. Inhibition of myostatin with emphasis on follistatin as a therapy for muscle disease. Muscle Nerve. 2009;39(3):283-296.

50. Rose FF Jr, Mattis VB, Rindt H, Lorson CL. Delivery of recombinant follistatin lessens disease severity in a mouse model of spinal muscular atrophy. Hum Mol Genet. 2009;18(6):997-1005.

51. Hill JJ, Davies MV, Pearson AA, et al. The myostatin propeptide and the follistatin-related gene are inhibitory binding proteins of myostatin in normal serum. $J$ Biol Chem. 2002;277(43):40735-40741.

52. Haidet AM, Rizo L, Handy C, et al. Long-term enhancement of skeletal muscle mass and strength by single gene administration of myostatin inhibitors. Proc Natl Acad Sci U S A. 2008;105(11):4318-4322.

53. Nakatani M, Takehara $Y$, Sugino $H$, et al. Transgenic expression of a myostatin inhibitor derived from follistatin increases skeletal muscle mass and ameliorates dystrophic pathology in $\mathrm{mdx}$ mice. FASEB $J$. 2008;22(2):477-487.
54. Tsuchida K. Activins, myostatin and related TGF-beta family members as novel therapeutic targets for endocrine, metabolic and immune disorders. Curr Drug Targets Immune Endocr Metabol Disord. 2004;4(2): $157-166$.

55. Lee SJ, Lee YS, Zimmers TA, et al. Regulation of muscle mass by follistatin and activins. Mol Endocrinol. 2010;24(10):1998-2008.

56. Gehrig SM, Ryall JG, Schertzer JD, Lynch GS. Insulin-like growth factor-I analogue protects muscles of dystrophic mdx mice from contraction-mediated damage. Exp Physiol. 2008;93(11): $1190-1198$

57. Dai Z, Wu F, Yeung EW, Li Y. IGF-IEc expression, regulation and biological function in different tissues. Growth Horm IGF Res. 2010;20(4):275-281.

58. Kumar A, Bhatnagar S, Kumar A. Matrix metalloproteinase inhibitor batimastat alleviates pathology and improves skeletal muscle function in dystrophin-deficient mdx mice. Am J Pathol. 2010;177(1): $248-260$.

59. Li H, Mittal A, Makonchuk DY, Bhatnagar S, Kumar A. Matrix metalloproteinase-9 inhibition ameliorates pathogenesis and improves skeletal muscle regeneration in muscular dystrophy. Hum Mol Genet. 2009;18(14):2584-2598.

60. Menazza S, Blaauw B, Tiepolo T, et al. Oxidative stress by monoamine oxidases is causally involved in myofiber damage in muscular dystrophy. Hum Mol Genet. 2010;19(21):4207-4215.

61. Buyse GM, van der Mieren G, Erb M, et al. Long-term blinded placebocontrolled study of SNT-MC17/idebenone in the dystrophin deficient mdx mouse: cardiac protection and improved exercise performance. Eur Heart J. 2009;30(1):116-124.

62. Dorchies OM, Wagner S, Buetler TM, Ruegg UT. Protection of dystrophic muscle cells with polyphenols from green tea correlates with improved glutathione balance and increased expression of $67 \mathrm{LR}$, a receptor for (-)-epigallocatechin gallate. Biofactors. 2009;35(3):279-294.

63. Townsend D, Yasuda S, Chamberlain J, Metzger JM. Cardiac consequences to skeletal muscle-centric therapeutics for Duchenne muscular dystrophy. Trends Cardiovasc Med. 2009;19(2):50-55.

64. Townsend D, Yasuda S, Metzger J. Cardiomyopathy of Duchenne muscular dystrophy: pathogenesis and prospect of membrane sealants as a new therapeutic approach. Expert Rev Cardiovasc Ther. 2007;5(1): 99-109.

65. Townsend D, Turner I, Yasuda S, et al. Chronic administration of membrane sealant prevents severe cardiac injury and ventricular dilatation in dystrophic dogs. J Clin Invest. 2010;120(4):1140-1150.

66. Love DR, Hill DF, Dickson G, et al. An autosomal transcript in skeletal muscle with homology to dystrophin. Nature. 1989;339(6219): $55-58$.

67. Tinsley JM, Potter AC, Phelps SR, Fisher R, Trickett JI, Davies KE. Amelioration of the dystrophic phenotype of mdx mice using a truncated utrophin transgene. Nature. 1996;384(6607):349-353.

68. Gilbert R, Nalbanoglu J, Tinsley JM, Massie B, Davies KE, Karpati G. Efficient utrophin expression following adenovirus gene transfer in dystrophic muscle. Biochem Biophys Res Commun. 1998;242(1): 244-247.

69. Gilbert R, Nalbantoglu J, Petrof BJ, et al. Adenovirus-mediated utrophin gene transfer mitigates the dystrophic phenotype of $\mathrm{mdx}$ mouse muscles. Hum Gene Ther. 1999;10(8):1299-1310.

70. Fisher R, Tinsley JM, Phelps SR, et al. Non-toxic ubiquitous overexpression of utrophin in the mdx mouse. Neuromuscul Disord. 2001; 11(8):713-721.

71. Finkel RS. Read-through strategies for suppression of nonsense mutations in Duchenne/Becker muscular dystrophy: aminoglycosides and ataluren (PTC124). J Child Neurol. 2010;25(9):1158-1164.

72. Burke JF, Mogg AE. Suppression of a nonsense mutation in mammalian cells in vivo by the aminoglycoside antibiotics G-418 and paromomycin. Nucleic Acids Res. 1985;13(17):6265-6272.

73. Bedwell DM, Kaenjak A, Benos DJ, et al. Suppression of a CFTR premature stop mutation in a bronchial epithelial cell line. Nat Med. 1997;3(11):1280-1284. 
74. Auld DS, Lovell S, Thorne N, et al. Molecular basis for the high-affinity binding and stabilization of firefly luciferase by PTC124. Proc Natl Acad Sci U S A. 2010;107(11):4878-4883.

75. Auld DS, Thorne N, Maguire WF, Inglese J. Mechanism of PTC124 activity in cell-based luciferase assays of nonsense codon suppression. Proc Natl Acad Sci U S A. 2009;106(9):3585-3590.

76. Wagner KR, Hamed S, Hadley DW, et al. Gentamicin treatment of Duchenne and Becker muscular dystrophy due to nonsense mutations. Ann Neurol. 2001;49(6):706-711.

77. Nudelman I, Rebibo-Sabbah A, Cherniavsky M, et al. Development of novel aminoglycoside (NB54) with reduced toxicity and enhanced suppression of disease-causing premature stop mutations. J Med Chem. 2009;52(9):2836-2845.

78. Hirst RC, McCullagh KJ, Davies KE. Utrophin upregulation in Duchenne muscular dystrophy. Acta Myol. 2005;24(3): 209-216.

79. Miura P, Jasmin BJ. Utrophin upregulation for treating Duchenne or Becker muscular dystrophy: how close are we? Trends Mol Med. 2006;12(3):122-129.

80. Mattei E, Corbi N, Di Certo MG, et al. Utrophin up-regulation by an artificial transcription factor in transgenic mice. PLoS One. 2007; 2(1):e774.

81. Nelson SF, Crosbie RH, Miceli MC, Spencer MJ. Emerging genetic therapies to treat Duchenne muscular dystrophy. Curr Opin Neurol. 2009;22(5):532-538.

82. Zamecnik PC, Stephenson ML. Inhibition of Rous sarcoma virus replication and cell transformation by a specific oligodeoxynucleotide. Proc Natl Acad Sci U SA. 1978;75(1):280-284.

83. Bennett CF, Swayze EE. RNA targeting therapeutics: molecular mechanisms of antisense oligonucleotides as a therapeutic platform. Annu Rev Pharmacol Toxicol. 2010;50:259-293.

84. Aartsma-Rus A, de Winter CL, Janson AA, et al. Functional analysis of 114 exon-internal AONs for targeted DMD exon skipping: indication for steric hindrance of SR protein binding sites. Oligonucleotides. 2005;15(4):284-297.

85. Wilton SD, Fall AM, Harding PL, McClorey G, Coleman C, Fletcher S. Antisense oligonucleotide-induced exon skipping across the human dystrophin gene transcript. Mol Ther. 2007;15(7):1288-1296.

86. Errington SJ, Mann CJ, Fletcher S, Wilton SD. Target selection for antisense oligonucleotide induced exon skipping in the dystrophin gene. J Gene Med. 2003;5(6):518-527.

87. Mann CJ, Honeyman K, Cheng AJ, et al. Antisense-induced exon skipping and synthesis of dystrophin in the mdx mouse. Proc Natl Acad Sci US A. 2001;98(1):42-47.

88. Mann CJ, Honeyman K, McClorey G, Fletcher S, Wilton SD. Improved antisense oligonucleotide induced exon skipping in the mdx mouse model of muscular dystrophy. J Gene Med. 2002;4(6): 644-654.

89. Aoki Y, Nakamura A, Yokota T, et al. In-frame dystrophin following exon 51-skipping improves muscle pathology and function in the exon 52-deficient mdx mouse. Mol Ther. 2010;18(11):1995-2005.

90. Rimessi P, Fabris M, Bovolenta M, et al. Antisense modulation of both exonic and intronic splicing motifs induces skipping of a DMD pseudoexon responsible for x-linked dilated cardiomyopathy. Hum Gene Ther. 2010;21(9):1137-1146.

91. Spitali P, Rimessi P, Fabris M, et al. Exon skipping-mediated dystrophin reading frame restoration for small mutations. Hum Mutat. 2009;30(11):1527-1534.

92. Yin H, Betts $\mathrm{C}$, Saleh AF, et al. Optimization of peptide nucleic acid antisense oligonucleotides for local and systemic dystrophin splice correction in the $\mathrm{mdx}$ mouse. Mol Ther. 2010;18(4): 819-827.

93. Saito T, Nakamura A, Aoki Y, et al. Antisense PMO found in dystrophic dog model was effective in cells from exon 7-deleted DMD patient. PLoS One. 2010;5(8):e12239.

94. Bosone I, Bortolotto S, Mongini T, et al. Late onset and very mild course of Xp21 Becker type muscular dystrophy. Clin Neuropathol. 2001;20(5):196-199.
95. Gospe SM Jr, Lazaro RP, Lava NS, Grootscholten PM, Scott MO, Fischbeck KH. Familial X-linked myalgia and cramps: a nonprogressive myopathy associated with a deletion in the dystrophin gene. Neurology. 1989;39(10):1277-1280.

96. Heald A, Anderson LV, Bushby KM, Shaw PJ. Becker muscular dystrophy with onset after 60 years. Neurology. 1994;44(12):2388-2390.

97. Sherratt TG, Vulliamy T, Dubowitz V, Sewry CA, Strong PN. Exon skipping and translation in patients with frameshift deletions in the dystrophin gene. Am J Hum Genet. 1993;53(5):1007-1015.

98. Lu QL, Morris GE, Wilton SD, et al. Massive idiosyncratic exon skipping corrects the nonsense mutation in dystrophic mouse muscle and produces functional revertant fibers by clonal expansion. $J$ Cell Biol. 2000;148(5):985-996.

99. Schatzberg SJ, Anderson LV, Wilton SD, et al. Alternative dystrophin gene transcripts in golden retriever muscular dystrophy. Muscle Nerve. 1998;21(8):991-998.

100. Ferrer A, Wells KE, Wells DJ. Immune responses to dystropin: implications for gene therapy of Duchenne muscular dystrophy. Gene Ther. 2000;7(17):1439-1446.

101. Takeshima Y, Nishio H, Sakamoto H, Nakamura H, Matsuo M. Modulation of in vitro splicing of the upstream intron by modifying an intra-exon sequence which is deleted from the dystrophin gene in dystrophin Kobe. J Clin Invest. 1995;95(2):515-520.

102. Pramono ZA, Takeshima Y, Alimsardjono H, Ishii A, Takeda S, Matsuo M. Induction of exon skipping of the dystrophin transcript in lymphoblastoid cells by transfecting an antisense oligodeoxynucleotide complementary to an exon recognition sequence. Biochem Biophys Res Commun. 1996;226(2):445-449.

103. Dunckley MG, Manoharan M, Villiet P, Eperon IC, Dickson G. Modification of splicing in the dystrophin gene in cultured mdx muscle cells by antisense oligoribonucleotides. Hum Mol Genet. 1998;7(7):1083-1090.

104. Wilton SD, Lloyd F, Carville K, et al. Specific removal of the nonsense mutation from the mdx dystrophin mRNA using antisense oligonucleotides. Neuromuscul Disord. 1999;9(5):330-338.

105. Cartegni L, Wang J, Zhu Z, Zhang MQ, Krainer AR. ESEfinder: a web resource to identify exonic splicing enhancers. Nucleic Acids Res. 2003;31(13):3568-3571

106. Desmet FO, Hamroun D, Lalande M, Collod-Béroud G, Claustres M, Béroud C. Human Splicing Finder: an online bioinformatics tool to predict splicing signals. Nucleic Acids Res. 2009;37(9):e67.

107. Aartsma-Rus A, Houlleberghs H, van Deutekom JC, van Ommen GJ, 't Hoen PA. Exonic sequences provide better targets for antisense oligonucleotides than splice site sequences in the modulation of Duchenne muscular dystrophy splicing. Oligonucleotides. 2010;20(2): 69-77.

108. Harding PL, Fall AM, Honeyman K, Fletcher S, Wilton SD. The influence of antisense oligonucleotide length on dystrophin exon skipping. Mol Ther. 2007;15(1):157-166.

109. Wee KB, Pramono ZA, Wang JL, MacDorman KF, Lai PS, Yee WC. Dynamics of co-transcriptional pre-mRNA folding influences the induction of dystrophin exon skipping by antisense oligonucleotides. PLoS One. 2008;3(3):e1844.

110. Arechavala-Gomeza V, Graham IR, Popplewell LJ, et al. Comparative analysis of antisense oligonucleotide sequences for targeted skipping of exon 51 during dystrophin pre-mRNA splicing in human muscle. Hum Gene Ther. 2007;18(9):798-810.

111. Adams AM, Harding PL, Iversen PL, Coleman C, Fletcher S, Wilton SD. Antisense oligonucleotide induced exon skipping and the dystrophin gene transcript: cocktails and chemistries. BMC Mol Biol. 2007;8:57.

112. Wang Q, Yin $\mathrm{H}$, Camelliti $\mathrm{P}$, et al. In vitro evaluation of novel antisense oligonucleotides is predictive of in vivo exon skipping activity for Duchenne muscular dystrophy. J Gene Med. 2010;12(4): 354-364.

113. Mitrpant C, Adams AM, Meloni PL, Muntoni F, Fletcher S, Wilton SD. Rational design of antisense oligomers to induce dystrophin exon skipping. Mol Ther. 2009;17(8):1418-1426. 
114. Wilton SD, Fletcher S. Splice modification to restore functional dystrophin synthesis in Duchenne muscular dystrophy. Curr Pharm Des. 2010;16(8):988-1001.

115. Spitali P, Heemskerk H, Vossen RH, et al. Accurate quantification of dystrophin mRNA and exon skipping levels in Duchenne muscular dystrophy. Lab Invest. 2010;90(9):1396-1402.

116. Arechavala-Gomeza V, Kinali M, Feng L, et al. Immunohistological intensity measurements as a tool to assess sarcolemma-associated protein expression. Neuropathol Appl Neurobiol. 2010;36(4):265-274.

117. Bushby K, Lochmüller H, Lynn S, Straub V. Interventions for muscular dystrophy: molecular medicines entering the clinic. Lancet. 2009;374(9704):1849-1856.

118. Aartsma-Rus A, Kaman WE, Bremmer-Bout M, et al. Comparative analysis of antisense oligonucleotide analogs for targeted DMD exon 46 skipping in muscle cells. Gene Ther. 2004;11(18):1391-1398.

119. Surono A, van Khanh T, Takeshima Y, et al. Chimeric RNA/ethylenebridged nucleic acids promote dystrophin expression in myocytes of Duchenne muscular dystrophy by inducing skipping of the nonsense mutation-encoding exon. Hum Gene Ther. 2004;15(8):749-757.

120. Fletcher S, Honeyman K, Fall AM, Harding PL, Johnsen RD, Wilton SD. Dystrophin expression in the mdx mouse after localised and systemic administration of a morpholino antisense oligonucleotide. J Gene Med. 2006;8(2):207-216.

121. Gebski BL, Mann CJ, Fletcher S, Wilton SD. Morpholino antisense oligonucleotide induced dystrophin exon 23 skipping in mdx mouse muscle. Hum Mol Genet. 2003;12(15):1801-1811.

122. Takeshima Y, Yagi M, Wada H, Matsuo M. Intraperitoneal administration of phosphorothioate antisense oligodeoxynucleotide against splicing enhancer sequence induced exon skipping in dystrophin mRNA expressed in mdx skeletal muscle. Brain Dev. 2005;27(7):488-493.

123. Aartsma-Rus A, Bremmer-Bout M, Janson AA, den Dunnen JT, van Ommen GJ, van Deutekom JC. Targeted exon skipping as a potential gene correction therapy for Duchenne muscular dystrophy. Neuromuscul Disord. 2002;12 Suppl 1:S71-S77.

124. Sirsi SR, Schray RC, Guan X, et al. Functionalized PEG-PEI copolymers complexed to exon-skipping oligonucleotides improve dystrophin expression in mdx mice. Hum Gene Ther. 2008;19(8):795-806.

125. Sirsi SR, Williams JH, Lutz GJ. Poly(ethylene imine)-poly(ethylene glycol) copolymers facilitate efficient delivery of antisense oligonucleotides to nuclei of mature muscle cells of mdx mice. Hum Gene Ther. 2005;16(11):1307-1317.

126. Rimessi P, Sabatelli P, Fabris M, et al. Cationic PMMA nanoparticles bind and deliver antisense oligoribonucleotides allowing restoration of dystrophin expression in the mdx mouse. Mol Ther. 2009;17(5): $820-827$.

127. Kim Y, Tewari M, Pajerowski JD, et al. Polymersome delivery of siRNA and antisense oligonucleotides. J Control Release. 2009; 134(2):132-140.

128. Sazani P, Astriab-Fischer A, Kole R. Effects of base modifications on antisense properties of 2'-O-methoxyethyl and PNA oligonucleotides. Antisense Nucleic Acid Drug Dev. 2003;13(3):119-128.

129. Fletcher S, Honeyman K, Fall AM, et al. Morpholino oligomermediated exon skipping averts the onset of dystrophic pathology in the mdx mouse. Mol Ther. 2007;15(9):1587-1592.

130. Jearawiriyapaisarn N, Moulton HM, Buckley B, et al. Sustained dystrophin expression induced by peptide-conjugated morpholino oligomers in the muscles of mdx mice. Mol Ther. 2008;16(9):1624-1629.

131. Moulton HM, Fletcher S, Neuman BW, et al. Cell-penetrating peptidemorpholino conjugates alter pre-mRNA splicing of DMD (Duchenne muscular dystrophy) and inhibit murine coronavirus replication in vivo. Biochem Soc Trans. 2007;35(Pt 4):826-828.

132. Moulton HM, Moulton JD. Morpholinos and their peptide conjugates: therapeutic promise and challenge for Duchenne muscular dystrophy. Biochim Biophys Acta. 2010;1798(12):2296-2303

133. Yin H, Moulton HM, Betts C, et al. Functional rescue of dystrophindeficient mdx mice by a chimeric peptide-PMO. Mol Ther. 2010; 18(10):1822-1829.
134. Morcos PA, LiY, Jiang S. Vivo-Morpholinos: a non-peptide transporter delivers Morpholinos into a wide array of mouse tissues. Biotechniques. 2008;45(6):613-614, 616, 618, passim.

135. Wu B, Li Y, Morcos PA, Doran TJ, Lu P, Lu QL. Octa-guanidine morpholino restores dystrophin expression in cardiac and skeletal muscles and ameliorates pathology in dystrophic mdx mice. Mol Ther. 2009;17(5):864-871.

136. Alter J, Lou F, Rabinowitz A, et al. Systemic delivery of morpholino oligonucleotide restores dystrophin expression bodywide and improves dystrophic pathology. Nat Med. 2006;12(2):175-177.

137. Lu QL, Mann CJ, Lou F, et al. Functional amounts of dystrophin produced by skipping the mutated exon in the mdx dystrophic mouse. Nat Med. 2003;9(8):1009-1014.

138. Lu QL, Rabinowitz A, Chen YC, et al. Systemic delivery of antisense oligoribonucleotide restores dystrophin expression in bodywide skeletal muscles. Proc Natl Acad Sci U S A. 2005;102(1): 198-203.

139. Jearawiriyapaisarn N, Moulton HM, Sazani P, Kole R, Willis MS Long-term improvement in mdx cardiomyopathy after therapy with peptide-conjugated morpholino oligomers. Cardiovasc Res. 2010;85(3):444-453.

140. Yin H, Moulton H, Betts C, Wood M. CPP-directed oligonucleotide exon skipping in animal models of Duchenne muscular dystrophy. Methods Mol Biol. 2011;683:321-338

141. Yin H, Moulton HM, Betts C, et al. A fusion peptide directs enhanced systemic dystrophin exon skipping and functional restoration in dystrophin-deficient mdx mice. Hum Mol Genet. 2009;18(22):4405-4414.

142. Vitiello L, Bassi N, Campagnolo P, et al. In vivo delivery of naked antisense oligos in aged mdx mice: analysis of dystrophin restoration in skeletal and cardiac muscle. Neuromuscul Disord. 2008;18(8): 597-605.

143. Malerba A, Thorogood FC, Dickson G, Graham IR. Dosing regimen has a significant impact on the efficiency of morpholino oligomerinduced exon skipping in mdx mice. Hum Gene Ther. 2009;20(9): 955-965.

144. Wu B, Lu P, Benrashid E, et al. Dose-dependent restoration of dystrophin expression in cardiac muscle of dystrophic mice by systemically delivered morpholino. Gene Ther. 2010;17(1):132-140.

145. Mitrpant C, Fletcher S, Iversen PL, Wilton SD. By-passing the nonsense mutation in the $4 \mathrm{CV}$ mouse model of muscular dystrophy by induced exon skipping. J Gene Med. 2009;11(1): 46-56.

146. Bremmer-Bout M, Aartsma-Rus A, de Meijer EJ, et al. Targeted exon skipping in transgenic hDMD mice: a model for direct preclinical screening of human-specific antisense oligonucleotides. Mol Ther. 2004;10(2):232-240.

147. Deconinck AE, Rafael JA, Skinner JA, et al. Utrophin-dystrophindeficient mice as a model for Duchenne muscular dystrophy. Cell. 1997;90(4):717-727.

148. Goyenvalle A, Babbs A, Powell D, et al. Prevention of dystrophic pathology in severely affected dystrophin/utrophin-deficient mice by morpholino-oligomer-mediated exon-skipping. Mol Ther. 2010;18(1):198-205.

149. Yokota T, Lu QL, Partridge T, et al. Efficacy of systemic morpholino exon-skipping in Duchenne dystrophy dogs. Ann Neurol. 2009;65(6): 667-676.

150. Ivanova GD, Arzumanov A, Abes R, et al. Improved cell-penetrating peptide-PNA conjugates for splicing redirection in HeLa cells and exon skipping in mdx mouse muscle. Nucleic Acids Res. 2008;36(20): 6418-6428.

151. Seow Y, Yin H, Wood MJ. Identification of a novel muscle targeting peptide in mdx mice. Peptides. 2010;31(10):1873-1877.

152. Takeshima Y, Yagi $M$, Wada $H$, et al. Intravenous infusion of an antisense oligonucleotide results in exon skipping in muscle dystrophin mRNA of Duchenne muscular dystrophy. Pediatr Res. 2006;59(5): 690-694. 
153. Crouch RJ, Dirksen ML. Ribonuclease H. In: Linn SM, Roberts RJ, editors. Nucleases. Cold Spring Harbor (NY): Cold Spring Harbor Laboratory Press; 1985:211-241.

154. Summerton J. Morpholino antisense oligomers: the case for an RNase H-independent structural type. Biochim Biophys Acta. 1999;1489(1): 141-158.

155. Warfield KL, Swenson DL, Olinger GG, et al. Gene-specific countermeasures against Ebola virus based on antisense phosphorodiamidate morpholino oligomers. PLoS Pathog. 2006;2(1):e1.

156. Van den Born E, Stein DA, Iversen PL, Snijder EJ. Antiviral activity of morpholino oligomers designed to block various aspects of Equine arteritis virus amplification in cell culture. J Gen Virol. 2005; 86(Pt 11):3081-3090.

157. Kipshidze N, Tsapenko M, Iversen P, Burger D. Antisense therapy for restenosis following percutaneous coronary intervention. Expert Opin Biol Ther. 2005;5(1):79-89.
158. Iversen PL, Arora V, Acker AJ, Mason DH, Devi GR. Efficacy of antisense morpholino oligomer targeted to c-myc in prostate cancer xenograft murine model and a phase I safety study in humans. Clin Cancer Res. 2003;9(7):2510-2519.

159. Sazani P, Weller DL, Shrewsbury SB. Safety pharmacology and genotoxicity evaluation of AVI-4658. Int J Toxicol. 2010;29(2): 143-156.

160. Grossman CM. The first use of penicillin in the United States. Ann Intern Med. 2008;149(2):135-136.

161. Dumonceaux J, Marie S, Beley C, et al. Combination of myostatin pathway interference and dystrophin rescue enhances tetanic and specific force in dystrophic mdx mice. Mol Ther. 2010;18(5):881-887.
The Application of Clinical Genetics

\section{Publish your work in this journal}

The Application of Clinical Genetics is an international, peer-reviewed open access journal that welcomes laboratory and clinical findings in the field of human genetics. Specific topics include: Population genetics; Functional genetics; Natural history of genetic disease; Management of genetic disease; Mechanisms of genetic disease; Counselling and

\section{Dovepress}

ethical issues; Animal models; Pharmacogenetics; Prenatal diagnosis; Dysmorphology. The manuscript management system is completely online and includes a very quick and fair peer-review system, which is all easy to use. Visit http://www.dovepress.com/testimonials.php to read real quotes from published authors. 